\title{
Intimations of Mortality: Stewart Parker's Hopdance
}

\section{Marilynn Richtarik}

\section{(2) OpenEdition \\ 1 Journals}

\section{Electronic version}

URL: http://journals.openedition.org/etudesirlandaises/5133

DOI: 10.4000/etudesirlandaises.5133

ISSN: 2259-8863

\section{Publisher}

Presses universitaires de Rennes

\section{Printed version}

Date of publication: 29 June 2017

Number of pages: $93-103$

ISBN: 978-2-7535-5495-5

ISSN: 0183-973X

\section{Electronic reference}

Marilynn Richtarik, «Intimations of Mortality: Stewart Parker's Hopdance », Études irlandaises [Online], 42-1 | 2017, Online since 29 June 2019, connection on 07 September 2019. URL : http:// journals.openedition.org/etudesirlandaises/5133; DOI : 10.4000/etudesirlandaises.5133 


\title{
Intimations of Mortality: Stewart Parker's Hopdance
}

\author{
Marilynn RICHTARIK \\ Georgia State University
}

\begin{abstract}
Northern Irish playwright Stewart Parker (1941-1988) also wrote poetry and experimental prose. His autobiographical novel Hopdance, which deals with the amputation of his left leg when he was nineteen years old, has been edited by his biographer Marilynn Richtarik and will be made available in 2017 by The Lilliput Press. This essay introduces and analyzes Hopdance, a previously unpublished work that sheds considerable light on Parker's preoccupations as a writer.
\end{abstract}

Keywords: Stewart Parker, contemporary fiction, amputation, embodiment, mortality.

\section{Résumé}

Le dramaturge nord-irlandais Stewart Parker (1941-1988) a aussi écrit des poèmes et de la prose expérimentale. Son roman autobiographique Hopdance, qui parle de l'amputation de sa jambe gauche lorsqu'il avait 19 ans, fait l'objet d'une édition critique élaborée par sa biographe Marilynn Richtarik qui sera publiée chez Liliput Press en 1917. Cet article propose une introduction à Hopdance, cuvre jusqu'alors inédite qui met en lumière les préoccupations artistiques de Parker.

Mots clés: Stewart Parker, fiction contemporaine, amputation, incarnation, mortalité.

Born in Belfast in 1941, Stewart Parker is best remembered today as one of the most accomplished Irish playwrights of the twentieth century. I spent the better part of twenty years researching and writing a critical biography of him that, by its very nature, emphasizes the author's human existence at a particular time and in specific places and argue, implicitly, that these were determining factors in the writing he produced. As a scholar, then, I am intimately engaged with the theme of this issue in at least two senses: the embodiment of the (Northern) Irish author, and the body of his work. Hopdance mattered crucially to Parker in both of these aspects, but it remained unpublished and, indeed, unfinished when he died in his late forties. It is a phantom limb that exerts a constant, invisible pressure on his corpus. In 2017, for the first time, readers will have the opportunity to encounter this work, in an edition compiled by me and published by The Lilliput Press in Dublin. In this essay, I introduce Hopdance, describing and analyzing the text. 


\section{The text of Hopdance}

Largely drafted in the early 1970s, Hopdance records Parker's state of mind and events from his life before, during, and after the bout with bone cancer that resulted in the amputation of his left leg when he was nineteen years old. In the immediate aftermath of this surgery, the physical dimension of his loss had overwhelmed any other response. For some time after his hospital stay ended, he recalled, "I was in terrible pain, I was in a stupor [...]. I was drifting through life in a dream" ". He came to believe that he had been in a state of shock, "so preoccupied with trying to survive that there [was] no time for thinking about anything else $^{2 "}$. After the shock wore off, a resolute determination to resume his life as if the amputation were merely a minor inconvenience had helped Parker smother his fear that the cancer might recur. Finally, in his late twenties, he decided the time had come to confront the "longer term psychological effects" of the fact that "a big bit of my body was gone to the grave".

In Hopdance, Parker transformed body into text, structuring his experience of amputation in a way that gave it meaning for him. His alter ego, Tosh (whose name signifies his callowness before this ordeal), is drifting through life before his cancer diagnosis, plagued by the twin "cankers" of a puzzling pain in his leg and a crippling loneliness. As the story of the amputation and its aftermath unfolds, Tosh begins to allow other people to share his suffering and moves closer to being able to make the great connection he has sought to another human being. His reflections on writing punctuate his process of maturation as a person. The amputation, Parker suggests, makes him a serious writer by forcing him into a more authentic relation to life, which "Starts with the wound. Ends with the kiss. For the lucky ones".

Parker worked on Hopdance sporadically in 1970 and 1971 and more steadily for two years after that, completing a draft in September 1973. He then began tinkering with the order of the scenes and typing up a final draft, but by early 1975 he was only nine pages into this work and acknowledged to himself that he had lost interest in the project. He had needed to write the book but could not summon the energy to polish and revise it. Instead, he put the manuscript aside, satisfied that it had served a private, therapeutic purpose for him. Later that year, his stage play Spokesong took the Dublin Theatre Festival by storm, inaugurating its triumphal progress around the globe, and soon after that Parker abando-

\footnotetext{
1. Stewart Parker, quoted in Niki Hill, "The Way We Were", Sunday News, 11 October 1987.

2. Stewart Parker, quoted in Caroline Walsh, "Stewart Parker", Irish Times, 13 August 1977.

3. Ibid.

4. Stewart Parker, Hopdance, ed. Marilynn Richtarik (with the assistance of Mary Grace Elliott), Dublin, Lilliput, 2017, p. 131.

5. Stewart Parker, Hopdance, p. 13.
} 
ned poetry and experimental prose in order to concentrate on drama. Hopdance remained unfinished business for him, however, and for the rest of his life at times of emotional crisis he returned to the manuscript. In 1988, after a new cancer diagnosis, he began working on it in a concerted fashion, having decided to add several scenes, only about half of which he managed to draft before he died. Parker, then, would have considered the novel as he left it (with a few scenes typed and most remaining in manuscript) only part of a projected whole, as his post-amputation physique was only part of a body.

Hopdance has fascinated me since June 1994, when Parker's executor, Lesley Bruce, allowed me to examine the manuscript. I knew the novel had never achieved the apotheosis Parker had envisaged for it, but to my mind it possessed a raw power even in its patchwork state. Although incomplete in Parker's terms, its form meant that there were no obvious holes or gaps in it. Fragmentary by nature, it readily accommodated new fragments - and could just as easily do without them. It therefore seemed possible to me to produce an edited version of Hopdance that, while not fulfilling Parker's ultimate vision for it, at least would not do violence to it.

Throughout the editorial process, my aim was to present, to the best of my ability, Parker's words, while minimizing the distraction presented by stylistic inconsistencies. I wanted the reader's experience of Hopdance to be that of encountering a new novel by a contemporary writer, so I avoided drawing attention to my procedures in the text itself, confining such comments to an introductory note and a series of appendices to the novel that illustrate its composition history. I am tremendously grateful to Parker's estate for allowing me to undertake this labour of love and giving me a free hand in its completion. I also acknowledge the invaluable assistance provided by Mary Grace Elliott, who helped me to check the typescript through several drafts and to formulate the rules by which the work would be carried on, and to my agent, Jonathan Williams, who embraced this unconventional project and managed to find a publisher for it. Antony Farrell and The Lilliput Press produced a beautiful edition of Hopdance for publication in 2017, enabling a general readership to discover what I have known now for over two decades: that Stewart Parker was a remarkable prose writer as well as an inventive dramatist.

\section{图 A reading of Hopdance}

In Hopdance, as in an earlier unpublished novel, Parker sought to challenge novelistic conventions regarding linear structure and character development by illustrating "simultaneity of event and stasis of character [...] pitted against an alarmingly unpredictable universe". Since, he argued, "life is largely lived, not in the present tense, but in the continuous past tense", he rejected "a step-by-step 
narrative" in favor of "a sequence of narrative images which will enact themselves simultaneously in the reader's mind when he has finished reading them by the intricate way in which they are connected ${ }^{6 "}$. As Tosh explains to his friend Harrison, "You take the fragments of your past [...]. You fit them into whatever mosaic seems to work. It has nothing to do with time or space" - except that, in his own case, "figments" might be a more appropriate description of them:

I remember single incidents with surrealistic intensity, they never happened the way they replay themselves in my head. Most of them were insignificant at the time, I've forgotten all the big production numbers. But these small moments obsess $\mathrm{me}^{7}$.

W. B. Yeats, one of Parker's most illustrious forebears in the Irish literary tradition, stressed the performative nature of writing. In an introduction written for a projected edition of his collected works, he famously declares that "a poet writes always of his personal life" but also insists that "he is never the bundle of accident and incoherence that sits down to breakfast; he has been reborn as an idea, something intended, complete". In other words, a poem's speaker may be a projection of the person who wrote it, but the "I" of the poem has no objective existence outside the text. "A novelist", Yeats allows, "might describe his accidence, his incoherence", but the poet must not: "He is more type than man, more passion than type ${ }^{8}$."

Much as he admired Yeats, Parker always found the example of James Joyce more congenial to his own sensibility. As Joyce does in A Portrait of the Artist as a Young Man (allusions to which abound in Hopdance), Parker regards his protagonist with both sympathy and ironic detachment. Like Joyce, he constructs his novel with scenes and vignettes representing his own youthful self. Both authors seem intent on highlighting the accidence and incoherence that Yeats decries, the way that human development proceeds in fits and starts. Joyce's Portrait presents a series of provisional resolutions that its immature hero, Stephen Dedalus, takes for permanent ones, ending with his exultant escape from Ireland to pursue his dream of becoming an artist - an upbeat conclusion exposed at the beginning of Ulysses as yet another underestimation on his part of the actual difficulty of growing up. Parker goes even further, arranging the episodes of Hopdance nonchronologically to undercut any illusion of linear development in Tosh's character.

6. Stewart Parker, handwritten notes dated 21 January 1968, quoted in Richtarik, "A Note on the Text of Hopdance" in Hopdance, p. XIII.

7. Stewart Parker, Hopdance, p. 14-15

8. W. B. Yeats, selections from "Essays for the Scribner Edition of Yeats's Collected Works (1937)" in James Pethica (ed.), Yeats's Poetry, Drama, and Prose, New York, Norton, 2000, p. 300-301. 
Tosh actually learns very little in the course of Hopdance. Most of what he knows in the scenes that come last chronologically he also knew in the scenes that come first. The most obvious example of this phenomenon concerns Tosh's attitude towards the opposite sex. Throughout Hopdance, he seeks a female soul mate to fulfill his every physical, mental, and emotional need, although the only women who genuinely excite his imagination are those who want nothing of the kind from him. Tosh's girlfriend, Prudence, with whom he attempts repeatedly to break up; a schoolboy crush named Ingrid; an old flame, Cora; a nurse he dates post-amputation; nameless girls he tries to seduce in various places - all represent, or have represented, Tosh's most exalted hopes for human connection. He acknowledges the absurdity of his impulses and actions, admitting to himself, in a scene two-thirds of the way through the novel, that

you see them either as harpies or Beatrices; first as a Beatrice, then as a harpy. Your masculine bequest, that. It has to end. You turn to a woman expecting God incarnate, you're hot for godhead more than maidenhead, it has to end?.

This inner dialogue echoes an earlier conversation with his friend Higgins, set pre-surgery, in which Tosh denounces the ideal of romantic love as "a con a fantasy a cruel lie": "That the answer to whatever ails you is some magic member of the opposite sex, or your own if that's your taste ${ }^{10}$." Despite this mature awareness, demonstrated at intervals from beginning to end of Hopdance, the penultimate scene of the novel, and probably the last one chronologically, depicts a desperate Tosh making a clumsy pass at Prudence's friend Florence, who, it turns out, has stopped by his flat mainly in order to tell him that Prudence would like to see him again. After all, Tosh is still a young man. Hopdance does not present his steady progression toward enlightenment, but rather flashes of illumination interspersed with episodes displaying the self-delusion he shares with everybody else.

Tosh's continually thwarted efforts to make a romantic connection alternate in the novel with scenes illustrating his incipient recognition of himself as part of a larger community of people who will die. In Hopdance, Tosh grapples with the classic adolescent questions about who he is and how he fits into the world. His coming of age, like that of Joyce's Stephen, is coloured by his conviction that he is destined to be a writer, but it is also complicated by his untimely brush with mortality. The most significant "accident" of all in the novel is, of course, Tosh's cancer, which transforms his ordinary teenage angst into a full-blown existential crisis, forcing him to test his theories against the reality of pain and suffering.

9. Stewart Parker, Hopdance, op. cit., p. 96. 10. Ibid., p. 20-21. 
In Illness as Metaphor, Susan Sontag analyzes the peculiar horror attaching to tuberculosis and cancer in the nineteenth and twentieth centuries. Fantasies about them flourish, she contends, "because TB and cancer are thought to be much more than diseases that usually are (or were) fatal. They are identified with death itself" - and this, in "advanced industrial societies," is increasingly hard to accept. "For those who live neither with religious consolations about death nor with a sense of death (or of anything else) as natural", she writes, "death is the obscene mystery, the ultimate affront, the thing that cannot be controlled. It can only be denied $^{11}{ }^{\prime \prime}$. The problem with death-denial, however, is that it entails a similar denial of the great truth about human life: it ends. As one of the characters in Parker's stage play Nightshade puts it,

we are the tribe which has lost the knowledge of how to die. In the boundless abundance of knowledge by which we act, this supreme skill has somehow been mislaid. Yet this one action - which we all dread - is the only one that's forced upon us all without exception. And we do it in shame and in confusion. Other tribes, who knew much less, at least knew this. They died with conviction and finesse. But we are entirely in the dark. And the black void of our ignorance spreads wider still. For a person begins to die at the moment of birth. So dying is an action that we perform throughout our lives. And so - at the heart's core - we are the tribe which has lost the knowledge of how to live ${ }^{12}$.

William Shakespeare expresses similar ideas more succinctly in King Lear, a play that provided Parker with both the title and the epigraph for Hopdance: "Men must endure/Their going hence, even as their coming hither;/Ripeness is all ${ }^{13}$."

Tosh does not discover that he will die as a result of the events of the novel. He knows this from the outset, like any competent adult, and is struggling to come to terms with mortality even before he understands the grave nature of his physical complaint. The fear of death, or at least a desire to find some meaning in it, has buttressed much religious conviction throughout human history, but Tosh finds little to sustain him in the faith he inherited. Having grown up surrounded by Northern Ireland's dreary sectarianism, he instinctively rejects organized religion.

11. Susan Sontag, Illness as Metaphor, New York, Farrar, Straus and Giroux, 1978, p. 18, 8, 55.

12. Stewart Parker, Nightshade, Dublin, Co-op Books, 1980, p. 52-53.

13. William Shakespeare, King Lear, ed. David Bevington et al., New York, Bantam, 1988, p. 120. Hopdance's epigraph consists of lines from a speech by Edgar in Shakespeare's play, a character who is feigning madness at the time: "The foul fiend haunts poor Tom in the voice of a nightingale. Hopdance cries in Tom's belly for two white herrings. Croak not, black angel; I have no food for thee." I am not aware, however, of many other explicit allusions to King Lear in the novel, and there is no explanation in the text of the Hopdance reference in the epigraph. 
Ulster Christianity, absurd and inadvertently destructive, hovers at the edges of Hopdance, epitomized in the figure of a devout lady in a hat who urges Tosh, lying in his hospital bed, to consider the pangs of Hell and prepare himself to meet God through self-abasing prayer. Still, in an early scene, Tosh identifies himself as

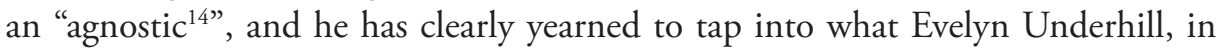
a classic volume on mysticism, describes as "the essential religious experience of $\operatorname{man}^{15}$ ", "the science or art of the spiritual life ${ }^{16 "}$ " "It must be easier", Tosh reflects, "if you have the machinery. Machinery of faith. [...] Machinery would keep you afloat, if I had any to believe in ${ }^{17 "}$.

Even the generalized faith of the mystics proves no match for his critical faculty, however: "Unitive Life. That fulsome jargon: the Mystic Way. I wanted to. I can't abide their sanctimony. Reverential earnestness. Repulsive prose ${ }^{18}$." His own spiritual impulses, such as they are, do not tend toward what Underhill terms "complete harmony with the transcendental order ${ }^{19}$ ". They express themselves, rather, in moments in which he grasps the extent of human frailty. In the same interior monologue in which he dismisses the claims of religion, Tosh asserts that

I could cry for bodies. [...] The young boy at the bus-stop. Just looking down on the pity of his thin shoulder-blades, the whole bus irradiated by that. For one moment. A cosmic smile. I could have embraced the world. The astonishing terrible spectacle of us all living our lives ${ }^{20}$.

During much of the novel, however, his own ailing body is wrenching him out of human communion, "dragging me away from that", as he puts it, "Drowning me. Deep down into my self ${ }^{21}$ ". Throughout Hopdance, Tosh seeks to understand who he really is - or, as he puts it at one point, "Where does I end $^{22}$ ?" He does not feel truly represented by his interactions with other people, since he is different with every person he encounters. Where, then, can he locate his essential self? Is it the voice in his head, the articulator of his consciousness? But what about that consciousness itself, which has recently centered itself on a throbbing pain? Surely the "I" exists in the body, too - is at least "Voice immer-

14. Stewart Parker, Hopdance, op. cit., p. 10.

15. Evelyn Underhill, Mysticism: A Study in the Nature and Development of Man's Spiritual Consciousness, New York, E. P. Dutton, 1941, p. viI.

16. Ibid., p. XIV.

17. Stewart Parker, Hopdance, op. cit., p. 28-29.

18. Ibid., p. 29.

19. Evelyn Underhill, Mysticism: A Study in the Nature and Development of Man's Spiritual Consciousness, op. cit., p. XIV.

20. Stewart Parker, Hopdance, op. cit., p. 29.

21. Ibid.

22. Ibid. 
sed in body ${ }^{23 "}$. But even this conception does not quite encompass Tosh's sense of himself.

Such questions are crystallized for him on the night before his amputation, when he first learns about the impending surgery. Left alone at last, he considers its implications:

Unknown was the only word for what was facing him. It might be death. Whatever that meant. It would certainly be some form of death. He pushed back the bed-clothes and placed his left leg on top of them. He wouldn't be the same person after they took it away. A quarter of him would have disappeared.

He pondered on where they would take the leg, what they would do with it. Medical students would practice on it, probably.[...] At any rate, it would have preceded the other three quarters of his ailing animal into the purely vegetable and mineral existence of dead matter. Or into the consciousness of which all matter partakes. Or into a spot from which it could conveniently fly out to be reunited with its hip on the Day of Judgement. It was generally assumed that a faith in such convictions was essential to face ordeals of suffering and death with equanimity. Yet Tosh felt entirely composed, and certain of nothing except for his own blind ignorance. The only resource he was aware of was the voice in his head itself, the fact of his own consciousness, and it was telling him that tomorrow when the knife and the saw went in, it itself would be drowned in gristle and blood and then he would have no resources at all. The fear created by such a prospect was an experience which entirely transcended the familiar everyday emotion which had frequently loosened his bowels and dried his mouth. It was a state of emotional refrigeration which had created the almost preternatural calm in which his thoughts were ordering themselves so composedly $\mathrm{y}^{24}$.

Parker told an interviewer in 1977 that "the worst experience a writer can have is one that is far beyond the reach of language, as pain is ${ }^{25}$. The initial effect of the amputation is to isolate Tosh in a region of himself that he could barely imagine before it. Immediately after his surgery, "Tosh was in a new dimension beyond messages ${ }^{26 "}$. He looks at a friend who has come to visit him

\footnotetext{
23. Ibid.

24. Ibid., p. 47-48.

25. Stewart Parker, quoted in Walsh, "Stewart Parker".

26. Stewart Parker, Hopdance, op. cit., p. 68.
} 
as though through the eye of a fish. He lay like a long still fish in the murk at the bottom of a tank. He lay there out of time and space, submerged in a fluid that dissolves language and touching, entirely alone with himself, at last ${ }^{27}$.

This experience seems at first a mere stripping-away of identity, but eventually Tosh finds that it has added something to his self-understanding. Much later, he explains to Florence that

I know my body's a behaviourist puppet [...]. The mind makes these bones talk. And the words are all we have. And beyond the words and the mind is where you feel you live. An illusory place, probably, a void, a necessary fiction. I'm very attached to that word, soul ${ }^{28}$.

None the less, Tosh remains what he calls "a faithful subject of the secular realm ${ }^{29 "}$. His realizations in extremis drive him towards union, not with God, but with other human beings. A hospital ward, he tells Prudence, is one of the "most public places in the world", but also one of the places "where people are most trapped in themselves":

The beds are all in rows [...] But everybody believes that their suffering's unique to themselves, it can't be shared, and what's happening to all the others is just an abstraction called pain or sickness, not the real actual hell that they're in. And the visitors all grieve for their own private person, but all this private grief is going on in a vast company of isolated grieving visitors. [...] If you step back and observe in these places, you get a kind of desperate, hilarious feeling that we're all identical heads on a single body, but none of us can conceive that, because all the heads are blind. We've got everything in common including a conviction of personal uniqueness ${ }^{30}$.

In time, Tosh comes to believe that "It's only through each other that we even begin to exist at all ${ }^{31}$ ", and he grounds his new attitude in his visceral apprehension of human vulnerability.

Tosh's periodic visits to the limb-fitting centre reinforce his sense of himself as "badged for life ${ }^{32}$ " by his narrow escape from death. On his first visit, to be fitted for a crude pylon limb, Tosh studies his fellow clients in the waiting room:

\footnotetext{
27. Ibid.

28. Ibid., p. 133.

29. Ibid.

30. Ibid., p. 111.

31. Ibid., p. 133.

32. Ibid., p. 91.
} 
He scanned the line of feet opposite. One foot of each pair sat cocked on its heel at an odd angle; in two cases, a shiny brown patch of leg visible above the top of the sock contrasted oddly with the hairy whiteness of the corresponding patch alongside it. By these signs shall we be known. Tosh raised his eyes discreetly and scrutinised the faces: a young red-haired country boy, a heavy-set man with hair in his nostrils, a thin old man with violet strings of veins across the backs of his hands. It had not occurred to him till now that he was a member of a freemasonry. A novice arrived for initiation ${ }^{33}$.

A subsequent appointment finds him

fascinated by how their appearances from the waist up, including his own, proclaimed an almost caricatured identity: whilst from the waist down, they were equally trouserless, each with one whole white and hairy leg and one longer or shorter stump of its fellow ${ }^{34}$.

All the patients he encounters at the limb-fitting centre share with him some form of the bodily lack that is an emblem of their mortality - which is to say their humanity.

Recognitions like these confirm Tosh's pre-existing egalitarianism: given such a commonality, all differences must appear trivial indeed. In the final scene of Hopdance, which takes place chronologically about midway through Tosh's ordeal, Tosh, still on crutches, "poles his way" through the windy city. Spying a one-legged beggar sitting on the footpath, Tosh approaches him. The last lines of the novel, which shift significantly from third to first person, highlight the restorative power of human connection and of story-telling:

Tosh pulls off the crutches from his arms and slides down beside the man. Together they look around them. He gives the man a cigarette, takes one for himself.

- What's your story, son? the man asks him then.

So I tell him my story. And at last free. Peace, for a brief spell, at least. Peace $^{35}$.

Although readers know that nothing has been settled for good - nothing ever is, as long as one remains alive - Hopdance ends on an affirmative note.

Tosh identifies a similar "confessional fever" as the essence of the "artistic impulse" in an earlier scene in which he describes to Harrison his idea for a stage play based on Samuel Taylor Coleridge's “The Rime of the Ancient Mariner": "It's 
the obsessive need to rehearse your memory of hell. If you don't enact it from time to time, it'll rend out your heart ${ }^{36}$." Clearly Hopdance served such a purpose for Parker, who never made any attempt to publish it in his lifetime, but he also saw the value of honest communication between writers and readers. On 17 May 1966 - the fifth anniversary of his amputation - he wrote an essay on the nature and purpose of art that begins with his expression of "A total conviction that life as we understand it is moving towards annihilation ${ }^{37 "}$. Authors of the past, he asserts, wrote with an awareness of themselves as part of an ongoing tradition; contemporary writers have neither an audience with a sense of the history of this tradition nor any reason to believe that there will be anyone left to read their work in a generation or two. Why, then, bother to write? For himself, Parker declares, art allows him "to prepare himself for my own death [...] but also to prepare himself for the larger death of which I am a tiny part ${ }^{38}$ ". In this way, he admits, art is fundamentally "a communion with yourself $\mathrm{f}^{39}$ ", but it can also be more than that because

the artist is simply a man with a more than average distinctiveness and persuasiveness and originality in his voice, one who can not only offer a worthwhile vision of his own, but can also help people to find the right words or perceptions or images or tones of voice to clarify and communicate their personal truths. That is his job now, just as it has always been, and, if anything, it is more important now than ever before, and less possible ${ }^{40}$.

As Tosh leaves the limb-fitting centre for the last time in Hopdance, having just received his first articulated leg, a prosthesis with a knee joint that does not have to be worked manually, the narrator observes that he "emerged into the world, moving with a gingerly limp on a stick, with a whole body again to all appearances $^{41}$ ". Parker here offers his readers a compact metaphor for the survival of trauma - not least the trauma of knowing, and believing, that death is not just for other people.

\footnotetext{
36. Ibid., p. 57.

37. Stewart Parker, untitled manuscript essay dated 17 May 1966, included as an appendix to the Lilliput edition of Hopdance, p. 147.

38. Ibid., p. 149.

39. Ibid.

40. Ibid., p. 152.

41. Stewart Parker, Hopdance, op. cit., p. 129.
} 